\title{
PROFIL PEMANFAATAN LITERASI TEKNOLOGI DAN INFORMASI (TIK) OLEH PENILIK KOTA CIMAHI
}

\author{
Ifah Cholifah ${ }^{1}$, Ansori $^{2}$, Dinno Mulyono ${ }^{3}$ \\ 1, 2, 3 Program Studi Pendidikan Masyarakat IKIP Siliwangi, Cimahi, Jawa Barat, Indonesia \\ 1ifahcholifah1@gmail.com, ${ }^{2}$ ansoryalb@ikipsiliwangi.ac.id, ${ }^{3}$ dinno@ikipsiliwangi.ac.id
}

Received: April, 2020; Accepted: Mei, 2020

\begin{abstract}
The development of information and communication technology (ICT) at this time cannot be avoided by various parties. This development has positive and negative impacts on human life. However, these impacts can be managed by humans themselves such as by studying and utilizing these developments in daily life, there will be many positive impacts felt, one of which facilitates the search and dissemination of information, as well as accelerating and facilitating work. However, in reality utilizing ICT in daily life in accordance with the work of each individual has not been fully implemented. Therefore, this research was carried out with the aim to find out the profile of the use of ICT by penilik in the Cimahi city education department. The instrument used was a questionnaire that was developed in accordance with ICT literacy level indicators. The results of his research show that the use of ICT by the penilik in the Cimahi city education office is in the medium category or can be interpreted quite well
\end{abstract}

Keywords: penilik, literacy, ICT

\begin{abstract}
Abstrak
Perkembangan teknologi informasi dan komunikasi (TIK) pada saat ini tidak dapat dihindari oleh berbagai pihak. Perkembangan ini memberikan dampak yang positif dan negatif bagi kehidupan manusia. Akan tetapi dampak tersebut dapat di kelola oleh manusia itu sendiri seperti dengan mempelajari dan memanfaatkan perkembangan tersebut dalam kehidupan sehari-hari maka akan banyak dampak positif yang dirasakan salah satunya mempermudah pencarian dan penyebaran informasi, serta mempercepat dan mempermudah pekerjaan. Akan tetapi dalam kenyataannya memanfaatkan TIK dalam kehidupan sehari-hari sesaui dengan pekerjaan masing-masing individu belum sepenuhnya dilaksanakan. Oleh karana itu, dilaksanakan penelitian ini dengan tujuan untuk mengetahui profil pemanfaatan TIK oleh penilik di lingkungan dinas pendidikan kota Cimahi. Intrumen yang digunakan adalah angket yang dikembangkan sesuai dengan indikator tingkat literasi TIK. Hasil penelitiannya menunjukan bahwa pemanfaatan TIK oleh penilik di lingkungan dinas pendidikan kota Cimahi berada pada kategori sedang atau dapat diartikan cukup baik.
\end{abstract}

Kata Kunci: penilik, literasi, TIK

How to Cite: Cholifah, Ansori \& Mulyono. (2020). Profil Pemanfaatan Literasi Teknologi Dan Informasi (TIK) Oleh Penilik Kota Cimahi. Comm-Edu (Community Education Journal) 3 (2), 174-180.

\section{PENDAHULUAN}

Perkembangan teknologi dan komunikasi (TIK) semakin hari semakin berkembang. Perkembangan TIK pada saat ini tidak dapat dihindari oleh siapapun, sangat mempengaruhi kehidupan manusia, dan memiliki peran penting diberbagai aspek kehidupan manusia. Oleh karena itu, maka untuk bertahan dan meningkatkan kulaitas hidup di era seperti saat ini yaitu dengan cara mempelajari dan berupaya memanfaatkannya dalam kehidupan sehari-hari hal ini 
sejalan dengan yang dikemukakan oleh Restiyani, dkk (2014) information and Communication Technology (ICT) plays an important role in society when we take into account the social, cultural and economic role of computers and the Internet. Oleh karena itu, memanfaatkan TIK dalam kehidupan sehari-hari salah satunya dalam aspek pendidikan menjadi yang sangat penting dilakukan pada saat ini.

Pemanfaatan TIK dalam aspek pendidikan di Indonesia telah di atur oleh pemerintah melalui Permendiknas nomor 16 tahun 2007 tentang standar kualifikasi akademik dan komptensi guru. Salah satu Standar kompetensi guru Pendidikan Anak Usia Dini (PAUD) sampai dengan sekolah menengah pada kompetensi pedagogik adalah mampu memanfaatkan teknologi informasi dan komunikasi untuk kepentingan pembelajaran yang diampu dan Permendiknas nomor 98 tahun 2014 tentang standar kualifikasi akademik dan kompetensi penilik. Salah satu kompetensi supervisi akademik penilik adalah memotivasi pendidik untuk memanfaatkan teknologi informasi dalam pembelajaran/ bimbingan pada program satuan PAUDNI. Berdasarkan pernyataan tersebut kemampuan pendidik dan penilik dalam memanfaatkan TIK sangat penting untuk terus dikembangkan.

Pemanfaatan TIK yang berkembang di masyarakat saat ini komputer, laptop, printer, projector, handphone dan internet. TIK terdiri dari dua jenis yaitu hardware atau perangkat keras berupa fisik yang dapat disentuh sedangkan software yaitu perangkat lunak berupa sistem yang dapat menjalankan suatu program. Software dapat berupa aplikasi, operating system (OS), atapun konten lainnya (Siahaan, 2009). Apabila pemanfaatan TIK oleh guru dan penilik dalam kegiatan pendidikan dapat berjalan dengan baik maka akan mampu meningkatkan kualitas pendidik, kualitas penilik, dan tentunya kualitas pembelajaran dan kualitas pembinaan. Dengan begitu diharapkan akan dapat meningkatkan kualitas pendidikan secara menyeluruh. Akan tetapi, pada kenyataannya pemanfaatan TIK dalam kegiatan pengelolaan dan pembinaan di bidang pendidikan belum dapat dikatan maksimal.

Penelitian ini berdasar pada penelitian sebelumnya yang dilakukan oleh Restiyani, dkk (2004) dengan judul profil pemanfaatan teknologi dan komunikasi sebagai media dan sumber pembelajaran oleh guru biologi yang hasil penelitiannya yaitu menunjukkan bahwa secara individu persentase literasi TIK guru biologi berdasarkan persepsi guru sudah mencapai kategori baik dan hasil tes kompotensi dasar TIK terkait literasi TIK pun menunjukkan bahwa kompetensi TIK guru biologi sudah masuk kategori baik hingga sangat baik. Penelitian selajutnya dilaksanakan oleh Saleh (2015) dengan judul literasi informasi dan komunikasi (TIK) masyarakat di kawasan Mamminasata yang hasilnya yaitu menunjukkan bahwa pengguna TIK di kawasan Mamminasata belum merata, yaitu masih didominasi oleh kelompok usia muda dan kelompok masyarakat yang berpendidikan tinggi. Berdasarkan hasil peneleitian tersebut belum adanya penelitian yang membahas tentang profil pemanfatan TIK oleh penilik maka dilaksanakan penelitian ini dengan tujuan untuk mengetahui sejauhmana pemanfaatan TIK oleh penilik di lingkungan pendidikan kota Cimahi.

Indikator kemampuan pemanfaatan TIK oleh penilik pada penelitian ini dikembangkan berdasar pada Personal-Capabilty Maturity Model (P-CMM), ICT-Literacy (Telematika Indonesia, 2004) seorang individu dapat dikategorikan atas lima tingkat yaitu: 
176 Cholifah, Ansori, Mulyono, Profil Pemanfaatan Literasi Teknologi Dan Informasi (TIK) Oleh Penilik Kota Cimahi 
Tabel 1. Tingkat Literasi TIK

\begin{tabular}{cl}
\hline Tingkat & \multicolumn{1}{c}{ Keterangan } \\
\hline 0 & $\begin{array}{l}\text { Jika seorang individu sama sekali tidak tahu dan tidak peduli akan pentingnya } \\
\text { informasi dan teknologi untuk kehidupan sehari-hari. }\end{array}$ \\
\hline 1 & $\begin{array}{l}\text { Jika seorang individu pernah memiliki pengalaman satu dua kali, dimana } \\
\text { informasi merupakan sebuah komponen penting untuk pencapaian keinginan } \\
\text { dan pemecahan masalah, dan telah melibatkan teknologi informasi untuk } \\
\text { mencarinya }\end{array}$ \\
\hline 2 & $\begin{array}{l}\text { Jika seorang individu telah berkali-kali menggunakan teknologi untuk } \\
\text { membantu aktivitas sehari-hari dan telah memiliki pola keberulangan dalam } \\
\text { peggunaannya. }\end{array}$ \\
\hline 3 & $\begin{array}{l}\text { Jika seorang individu telah memiliki standar penguasaan dan pemahaman } \\
\text { terhadap informasi maupun teknologi yang diperlukannya, dan secara konsisten } \\
\text { mempergunakan standar tersebut sebagai acuan penyelenggaraan aktivitas } \\
\text { sehari-hari. }\end{array}$ \\
\hline 4 & $\begin{array}{l}\text { Jika seorang individu telah sanggup meningkatkan secara signifikan (dapat } \\
\text { dinyatakan kuantitatif) kinerja aktivitas kehidupan sehari-harinya melalui } \\
\text { pemanfaatan informasi dan teknologi. }\end{array}$ \\
\hline 5 & $\begin{array}{l}\text { Jika seorang individu telah menganggap informasi dan teknologi sebagai bagian } \\
\text { tidak terpisahkan dari aktivitas sehari-hari, dan secara langsung maupun tidak } \\
\text { langsung telah mewarnai perilaku dan budaya hidupnya (bagian dari } \\
\text { information society atau manusia berbudaya informasi). }\end{array}$ \\
\hline
\end{tabular}

Berdasarkan tingkat literasi TIK di atas indikator pada penelitian ini dimana penilik dikatakan mampu memanfaatkan TIK adalah sebagai berikut:

Tabel 2. Indikator pemanfaatan TIK oleh Penilik

\begin{tabular}{cl}
\hline Indikator & \multicolumn{1}{c}{ Keterangan } \\
\hline $\mathrm{A}$ & $\begin{array}{l}\text { Mencari informasi-informasi yang berkaitan dengan tugas dan fungsi penilik } \\
\text { menggunakan teknologi informasi dan komunikasi }\end{array}$ \\
\hline $\mathrm{B}$ & $\begin{array}{l}\text { Menyebarkan informasi-informasi yang diperoleh dalam melaksankan tugas } \\
\text { dan fungsi sebagai penilik menggunakan teknologi informasi dan komunikasi }\end{array}$ \\
\hline $\mathrm{C}$ & $\begin{array}{l}\text { Menggunakan teknologi informasi untuk membantu dalam pelaksanaan tugas } \\
\text { dan fungsi sebagai penilik }\end{array}$ \\
\hline $\mathrm{D}$ & $\begin{array}{l}\text { Meningkatkan secara signifikan (dapat dinyatakan kuantitatif) kinerja sebagai } \\
\text { penilik melalui pemanfaatan informasi dan teknologi. }\end{array}$ \\
\hline $\mathrm{E}$ & $\begin{array}{l}\text { Jika seorang penilik telah menganggap informasi dan teknologi sebagai bagian } \\
\text { tidak terpisahkan dalam menjalakan fungsi dan tugas sebagai penilik }\end{array}$ \\
\hline
\end{tabular}

berdasarkan indikator di atas maka akan terlihat bagaimana pemanfaatan TIK oleh penilik dalam menalajankan tugas dan fungsinya. Diharapkan hasil penelitian ini dapat menjadi tolak ukur peningkatan pemanfaatan TIK dalam bidang pendidikan khusunya oleh penilik di lingkungan pendidikan kota Cimahi.

\section{METODE}

Penelitian yang digunkan pada penelitian ini adalah penelitian deskriptif dengan metode survei Subjek penelitian ini adalah seluruh penilik kota Cimahi yang berjumlah empat orang. Instrumen yang digunakan pada penelitian yaitu angket tentang tentang poemanfaatan TIK oleh 
penilik yang dikembangkan sesuai dengan indikator yang telah dijelaskan sebelumnya. Adapun rubrik dari indikator-indikator tersebut adalah sebagai berikut:

Tabel 3. Rubrik Indikator A

3 Apabila mencari informasi yang berkaitan dengan tugas dan fungsi penilik menggunakan tiga aplikasi pencari informasi

2 Apabila mencari informasi yang berkaitan dengan tugas dan fungsi penilik menggunakan dua aplikasi pencari informasi

1 Apabila mencari informasi yang berkaitan dengan tugas dan fungsi penilik menggunakan satu aplikasi pencari informasi

$0 \quad$ Apabila tidak pernah mencari informasi yang berkaitan dengan tugas dan fungsi penilik menggunakan aplikasi pencari informasi

Tabel 4. Rubrik Indikator B

3 Apabila mencari informasi yang berkaitan dengan tugas dan fungsi penilik menggunakan tiga aplikasi pencari informasi

2 Apabila mencari informasi yang berkaitan dengan tugas dan fungsi penilik menggunakan dua aplikasi pencari informasi

1 Apabila mencari informasi yang berkaitan dengan tugas dan fungsi penilik menggunakan satu aplikasi pencari informasi

$0 \quad$ Apabila tidak pernah mencari informasi yang berkaitan dengan tugas dan fungsi penilik menggunakan aplikasi pencari informasi

Tabel 5. Rubrik Indikator C

3 Apabilaselalu menggunakan teknologi informasi untuk membantu dalam pelaksanaan tugas dan fungsi sebagai penilik

2 Apabila sering menggunakan teknologi informasi untuk membantu dalam pelaksanaan tugas dan fungsi sebagai penilik

1 Apabilakadang-kadang menggunakan teknologi informasi untuk membantu dalam pelaksanaan tugas dan fungsi sebagai penilik

0 Apabila tidak pernah menggunakan teknologi informasi untuk membantu dalam pelaksanaan tugas dan fungsi sebagai penilik

Tabel 6. Rubrik Indikator D

1 Apabila telah meningkatkan secara signifikan (dapat dinyatakan kuantitatif) kinerja sebagai penilik melalui pemanfaatan informasi dan teknologi.

$0 \quad$ Apabila belum meningkatkan secara signifikan (dapat dinyatakan kuantitatif) kinerja sebagai penilik melalui pemanfaatan informasi dan teknologi.

Tabel 7. Rubrik Indikator E

1 Apabila seorang penilik telah menganggap informasi dan teknologi sebagai bagian tidak terpisahkan dalam menjalakan fungsi dan tugas sebagai penilik

$0 \quad$ Apabila seorang penilik belum menganggap informasi dan teknologi sebagai bagian tidak terpisahkan dalam menjalakan fungsi dan tugas sebagai penilik

Data yang diperoleh dari hasil angket diolah secara kuantitaif berdasarkan rubrik dari indikator di atas. Setelah data tersebut di olah kemudian dianalisis hasil analisis tersebut dijadikan dasar untuk penarikan kesimpulan. 


\section{HASIL DAN PEMBAHASAN}

\section{Hasil}

Berdasarkan hasil survei menggunakan angket diperoleh profil pemanfaatan teknologi informasi dan komunikasi (TIK) oleh Penilik di lingkungan kota Cimahi yaitu sebagai berikut:

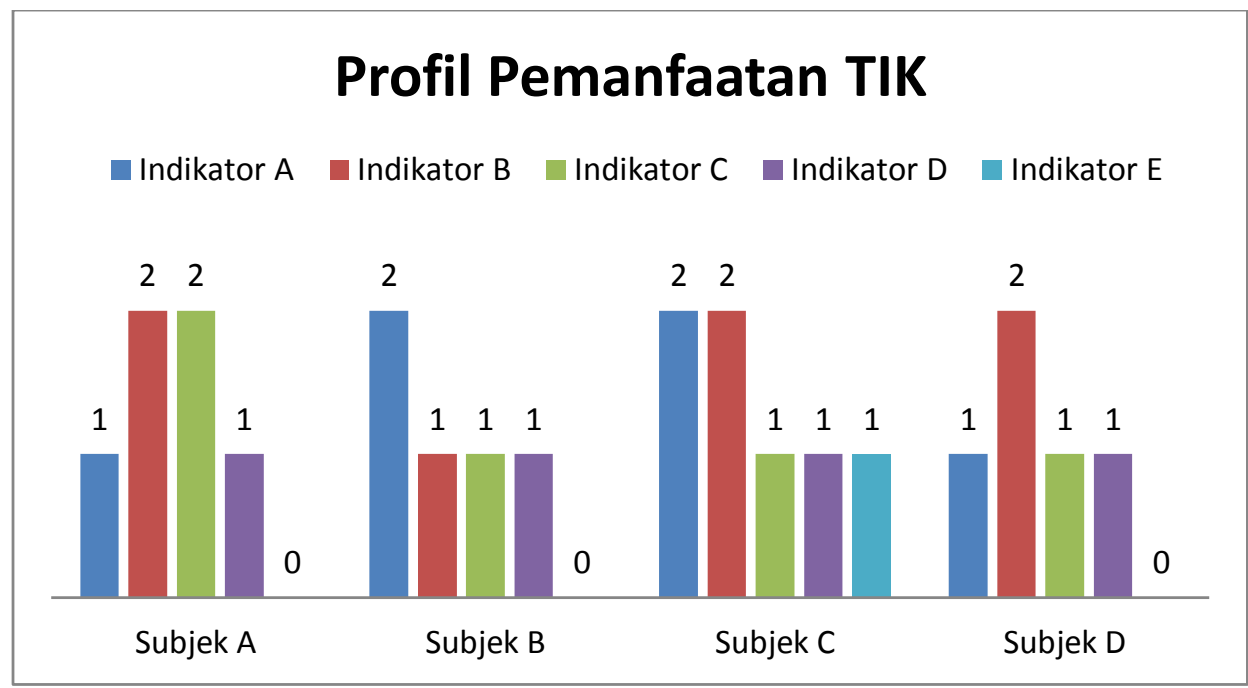

Grafik 1. Profil pemanfaatan TIK oleh Penilik

Berdasarkan grafik 1 tersebut, pemanfaatan TIK oleh penilik di lingkungan dinas pendidikan kota Cimahi sudah cukup baik terlihat hampir semua indikator terpenuhi walaupun belum maksimal. untuk lebih jelas indikator mana yang paling tinggi dalam pemanfaatan TIK dapat dilihat pda grafik di bawah ini.

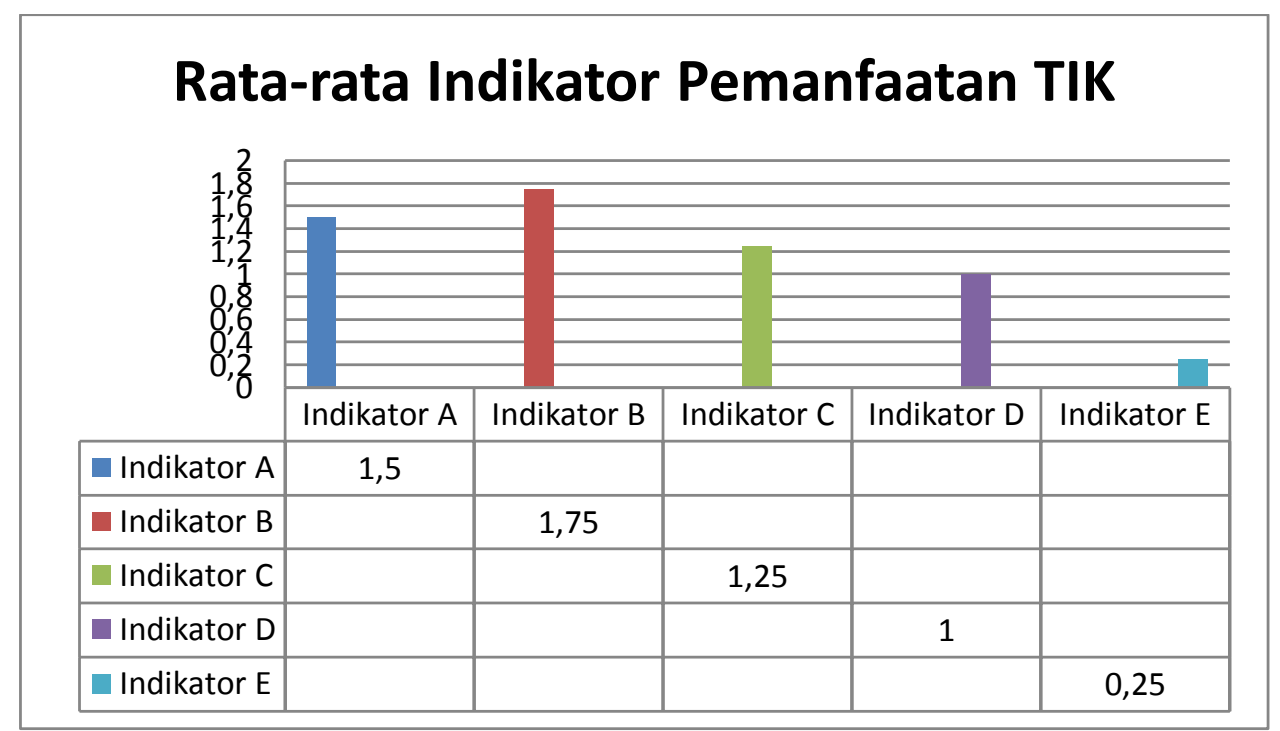

Grafik 2. Rata-rata indikator pemanfaatan TIK oleh Penilik

Berdasarkan grafik 2 tersebut, indikator yang paling tinggi rata-ratanya adalah indikator B yaitu menyebarkan informasi-informasi yang diperoleh dalam melaksanakan tugas dan fungsi sebagai penilik menggunakan teknologi informasi dan komunikasi dengan nilai rata-rata 1,75 menunjukan kategori sedang. Sedangkan indikator yang rata-ratanya paling rendah adalah indikator E yaitu jika seorang penilik telah menganggap informasi dan teknologi sebagai 
Oleh Penilik Kota Cimahi

bagian tidak terpisahkan dalam menjalakan fungsi dan tugas sebagai penilik dengan nilai ratarata 0,25 menunjukan kategori rendah.

\section{Pembahasan}

Pemanfataatan TIK oleh penilik di lingkungan dinas pendidikan kota Cimahi seperti yang telah dipaparkan pada bagian hasil menunjukan kategori cukup dengan beberapa indikator sudah dilaksanakan. Namun, ada satu indikator yang baru dilaksanakan oleh satu orang penilik yatu indikator $\mathrm{E}$ tentang jika seorang penilik telah menganggap informasi dan teknologi sebagai bagian tidak terpisahkan dalam menjalakan fungsi dan tugas sebagai penilik. Hal ini terjadi karena pemanfaatan TIK belum memiliki peran yang sangat penting dalam kegiatan yang berkaitan dengan tugas dan fungsi penilik. Faktor-faktor yang mempengaruhi hal tersebut salah satunya belum terbiasa mengintegrasikan TIK dalam kegiatan yang berkaitan dengan tugas dan fungsi sebagai penilik. Akibat dari tidak terbiasa maka munculah rasa canggung ketika menggunakan TIK dalam kegiatan-kegiatan (Rahayu \& Arga, 2019).

Indikator B tentang menyebarkan informasi-informasi yang diperoleh dalam melaksanakan tugas dan fungsi sebagai penilik menggunakan teknologi informasi dan komunikasi menjadi indikator yang paling tinggi diabandingkan indikator lainnya walaupun masih berada pada kategori sedang. Penyebaran informasi oleh penilik sudah melalui aplikasi-aplikasi TIK seperti email dan aplikasi media sosial lainnya. Media sosial yang digunakan baru satu sampai dua jenis media sosial sedangkan penyebaran informasi menggunakan email masih jarang dilaksanakan. Pemilihan media sosial oleh penilik karena penyebaran informasi melalui media sosial lebih mudah dibandingkan menggunakan email. Hal ini diakibatkan karena sebagian besar masyarakat sekarang mempunyai media sosial seperti whatsapp, telegram, instagram, facebook dan media sosial lainnya dan masyarakat Indonesia merupakan salah satu masyarakat yang paling sering menggunakan media sosial dalam kehidupan sehari-hari (Rohmiyati, 2018 dan Morissan, 2014). Sedangkan kecendrungan tidak menggunakan email diakibatkan masyarakat belum terbiasa dan masih kurang paham dengan funsi email meskipun setiap individu yang memiliki smartphone pasti memiliki email.

Indikator A tentang mencari informasi-informasi yang berkaitan dengan tugas dan fungsi penilik menggunakan teknologi informasi dan komunikasi menempati urutan kedua berdasarkan rata-rata nilai setiap indikator dengan nilai 1,5 menunjukan kategori sedang. Berdasarkan hasil dari angket penilik menggunakan aplikasi google dalam mencari berbagai informasi yang dibutuhkan. Pencarian informasi lebih sering dilakukan menggunkan smartphone dibandingkan dengan PC. Penilik merasakan dengan hadirnya google pencarian onformasi sangat mudah dan rata-rata dalam seminggu lebih dari tiga kali mencari informasi terkait dengan tugas dan fungsinya sebagai penilik.

Indikator $\mathrm{C}$ tentang menggunakan teknologi informasi untuk membantu dalam pelaksanaan tugas dan fungsi sebagai penilik berada pada kategori sedang. TIK yang diintegrasikan sesuai indikator tersebut seperti penggunaan aplikasi ms. Word dan ms. Excel dalam kegiatan yang dilaksanakan oleh penilik. Indikator D tentang meningkatkan secara signifikan (dapat dinyatakan kuantitatif) kinerja sebagai penilik melalui pemanfaatan informasi dan teknologi berada pada kategori cukup. Berdasarkan hasil wawancara dengan penilik, penilik merasa kinerja penilik meningkat ketika mengintegrasikan TIK dalam pelaksanaan kegiatan yang berkaitan dengan tugas dan fungsi penilik. Peningkatan kinerja tersebut seperti penilik sudah dapat menyebarkan informasi dengan cepat menggunakan media sosial kepada satuan-satuan yang dibinanya sehingga penyebaran inofrmasi lebih cepat dan mampu mengefisienkan waktu. 
Sebenarnya dengan mengintegrasikan TIK pekerjaan akan lebih mudah dan akan lebih cepat selesai dibandingkan dengan tidak mengintegrasikan TIK.

Berdasarkan pemaparan yang telah diaparkan tersebut, pemanfaatan TIK oleh penilik di lingkungan kota cimahi apabila merujuk pada hasil pengolahan dan analisis data menunjukan kategori cukup baik.

\section{KESIMPULAN}

Berdasarkan hasil penelitian yang telah di paparkan sebelumnya dapat disimpulkan bahwa pemanfaatan TIK oleh penilik di lingkungan kota Cimahi sudah cukup baik dilaksanakan walaupun dalam pelaksanaannya masih ada beberapa indikator yang masih belum maksimal. Hal ini diakibatkan belum terbiasanya mengintegrasikan TIK dalam kegiatan yang berkaitan dengan tugas dan fungsi penilik dan perlunya pemerataan dalam pemanfaatan TIK sehingga tidak hanya penilik tapi satuan-satuan program yang dibinanya pun dapat memanfaatkan TIK dalam kegiatan-kegiatan yang berkaitan dengan tugas dan fungsi.

\section{UCAPAN TERIMA KASIH}

Terima kasih kepada dinas pendidikan kota Cimahi yang telah memberikan ijin dan kesempatan melaksanakan penelitian ini sehingga penelitian ini dapat berjalan dengan lacar dan tujuannya tercapai.

\section{DAFTAR PUSTAKA}

Morissan. (2014). Media sosial dan partisipasi sosial di kalangan generasi muda. Jurnal visi komunikasi, volume 13 nomor 1 halaman 50-68

Rahayu, G., \& Arga, H. (2019). Influence of VBA-based Monopoly Game in Microsoft Excel as Teaching Material on Primary School Students' Cross-Cultural Competence in Social Studies Learning. Mimbar Sekolah Dasar, 6(2), 147-159. doi:https://doi.org/10.17509/mimbar-sd.v6i2.16935

Restiyanti, R., Juaeningsih, N., dan Herlanti, N. (2014). Profil pemanfaatan teknologi informasi dan komunikasi (TIK) sebagai media dan sumber pembelajaran oleh guru biologi. Jurnal EDUSAIN, volume 6 nomor Ihalaman 50-60.

Rohmiyati, Y. (2018). Analisis penyebaran informasi pada sosial media. Jurnal ANUVA, volume 2 nomor 1 .

Saleh, B. (2018). Literasi teknologi informasi dan komunikasi (TIK) masyarakat di kawasan mamminsata. Jurnal Pekommas, volume 18 nomor 3 halaman151-160.

Siahaan S. (2009). Pemanfaatan teknologi informasi dan komunikasi (TIK) dalam pembelajaran (modul pelatihan pengembangan dan pemanfaatan konten jardiknas). Jakarta: Departemen Pendidikan Nasional.

Telematika Indonesia. (2004). Kebijaan dan perkembangan tim koordinasi telematika Indonesia (TKPI). Jakarta: Kementerian Komunikasi dan Informasi RI. 